Federal Reserve Bank of Minneapolis

Research Department

\title{
The Macroeconomic Effects of Big Fiscal Shocks: The Case of World War II
}

\author{
Ellen R. McGrattan and Lee E. Ohanian
}

Working Paper 599

December 1999

\footnotetext{
*McGrattan, Federal Reserve Bank of Minneapolis; Ohanian, University of California, Los Angeles. The views expressed herein are those of the authors and not necessarily those of the Federal Reserve Bank of Minneapolis or the Federal Reserve System.
} 


\section{Introduction}

Hours worked rose 34 percent in the United States during World War II. This increase occurred even though the military draft reduced the labor force by 11 percent. Many economists and historians argue that neoclassical economic theory - conventional preferences, constant returns to scale technology, and competitive markets - cannot account for this large increase. Instead, they argue that accounting for economic performance during World War II requires departing from the neoclassical environment.

Some researchers, such as Mulligan (1998), argue that alternative preference specifications are required to account for the increase in hours worked. In particular, he suggests that patriotism may have played an important role in understanding the large increase in economic activity. Others, such as Rotemberg and Woodford (1991), argue that non-competitive markets are required to account for wartime economic performance. They suggest that imperfect competition and endogenous mark-ups may have played an important role in understanding the increase in hours worked and changes in wage rates.

In this paper, we re-examine whether standard theory can account for macroeconomic performance during World War II, including changes in hours worked, consumption, investment, and wages and interest rates. To do this, we construct a dynamic, general equilibrium model with a standard aggregate production function, standard preferences, and competitive markets. The model draws on earlier macroeconomic analyses of World War II by Braun and McGrattan (1993) and Ohanian (1997). ${ }^{1}$ The model includes some important wartime shocks: large increases in government purchases, uncertainty over the timing of the war, large reduc-

\footnotetext{
${ }^{1}$ Other recent papers that analyze the effects of large fiscal shocks include Rotemberg and Woodford (1992), Fatas and Mihov (1998), Ramey and Shapiro (1997), Blanchard and Perotti (1999), and Edelberg et al. (1999).) These papers use vector autoregressions (VAR) and report theVAR's impulse response functions of fiscal shocks to macroeconomic variables.
} 
tions in the labor force due to the draft, large changes in tax rates on factor incomes, rationing, and the possibility of a post-war depression. To understand the macroeconomic effect of each shock, we sequentially introduce one shock at a time to the model and compute the equilibrium. This shows how each shock affects prices and quantities. When all the shocks have been added, we compute the equilibrium of the economy and compare the predictions of the model for quantities and prices to actual quantities and prices.

Our main finding is that standard theory can account for economic performance during World War II. The model predicts a large increase in hours, significant decreases in consumption and private investment, and significant decreases in after-tax wages and interest rates. Both uncertainty over the timing of the end of the war and the possibility of a post-war depression are important factors behind the ability of the model to account for high labor input and low after-tax wages and interest rates. This result stands in sharp contrast to the conventional wisdom that alternative preferences or environments are required to successfully understand the U.S. wartime economy.

The remainder of the paper is organized as follows. Section 2 summarizes some of the arguments made against neoclassical theory for understanding World War II, and identifies the most puzzling wartime observations from the perspective of neoclassical theory. Section 3 presents the model economy, and discusses choices for parameter values. Section 4 presents the results, and section 5 concludes.

\section{Background}

Rotemberg and Woodford (1991,1992) and Mulligan (1998) argue that standard competitive theory cannot account for the movements in hours and wages during World War II. 
Standard theory predicts that temporary increases in government purchases leads to higher labor input through two channels: wealth effects and intertemporal substitution effects. Theory predicts that the negative wealth effect from high government purchases leads households to work harder and consume less. Theory also predicts that temporarily high government purchases lead to temporarily high interest rates. This intertemporal substitution channel also leads households to work harder and consume less. The higher labor input resulting from higher government purchases reduces labor productivity and the equilibrium real wage. (See, for example, Hall (1980), Barro (1981) and Aiyagari, Christiano and Eichenbaum (1992).) Rotemberg and Woodford (1991, 1992) argue that real wages did not decline during World War II, and therefore standard competitive theory cannot account for this change.

In World War II, increases in government spending were accompanied by large increases in tax rates. Standard theory predicts that increases in tax rates lead to a fall in after tax factor prices and therefore a fall in labor input. Mulligan (1998) argues that we did not observe a decline in hours or employment and therefore standard competitive theory cannot account for World War II.

Figure 1 summarizes these arguments graphically. Both graphs show labor supply and demand schedules. In the top panel, we consider a shift in the marginal utility $(\lambda)$ due to an increase in government spending. An increase in government spending has a wealth effect which leads to lower consumption (and higher marginal utility) and lower leisure. Equilibrium real wages $(w)$ are lower and equilibrium hours of work $(L)$ are higher. Rotemberg and Woodford use this prediction as evidence that the standard model could not account for events during World War II. They argued that both hours and real wages rose significantly during the war. Mulligan (1998) dismisses the view that wealth effects were important. He focuses 
instead on the fact that income tax rates rose significantly during the war. In the bottom panel of Figure 1, we show what happens when the tax rate goes from zero to positive. The labor supply shifts up, real wages rise, but after-tax real wages fall. As a result, equilibrium hours of work fall. Mulligan uses this prediction as evidence that the standard model could not account for events during World War II. He argues that after-tax real wages fell and hours rose significantly during the war.

In the next section, we describe in more detail the theory that Rotemberg and Woodford (1991,1992) and Mulligan (1998) critique. We then use this theory to determine the quantitative importance of wealth and price effects. To do this, we use spending and tax rates for the U.S. during World War II as inputs to our model and see what it predicts for allocations and prices.

\section{The Model}

Consider the problem of a representative family (or dynasty) with two types of members: "civilians" and "draftees." 2 Both types have period preferences given by $U(c, l)=\log (c)+V(1-$ $l$ ), where $V$ is a concave function. There are $N_{t}$ members of the family at date $t$ and $a_{t}$ of them are in the military. The family chooses consumption of both members, $c_{c}$ and $c_{d}$, investment in physical capital, $i_{p}$, and labor input, $l_{c}$, to maximize its expected lifetime utility:

$$
\max _{\left\{c_{c, t}, c_{d, t}, i_{p, t}, l_{c, t}\right\}} E \sum_{t=0}^{\infty} \beta^{t}\left\{\left(1-a_{t}\right) U\left(c_{c, t}, l_{c, t}\right)+a_{t} U\left(c_{d, t}, \bar{l}\right)\right\} N_{t}
$$

\footnotetext{
${ }^{2}$ This model of the draft, which explicitly preserves the representative agent construct, differs from that in Ohanian (1997), in which some families were hit by the draft, and others were not. Ohanian (1997) preserved the representative agent construct by assuming separable consumption and leisure and by assuming that military labor income and private labor income were identical.
} 
subject to

$$
\begin{aligned}
& \left(1-a_{t}\right) c_{c, t}+a_{t} c_{d, t}+i_{p, t}=\left(1-\tau_{k t}\right) r_{p, t} k_{p, t}+\left(1-\tau_{l, t}\right) w_{t}\left(1-a_{t}\right) l_{c, t}+\tau_{k, t} \delta k_{p, t}+T_{t} \\
& k_{p, t+1}=\left[(1-\delta) k_{p, t}+i_{p, t}\right] /\left(1+g_{n}\right)
\end{aligned}
$$

where $k_{p, t}$ is the beginning of period capital stock at date $t, r_{p, t}$ is the rental rate paid for that capital, $w_{t}$ is the wage rate in $t, \tau_{k, t}$ and $\tau_{l, t}$ are tax rates on capital and labor in $t$, respectively, and $T_{t}$ are transfers in $t$. All quantities are in per-capita terms and the growth rate of the population is given by $g_{n}$. Processes for $a_{t}, r_{p, t}, w_{t}, \tau_{k, t}, \tau_{l, t}$, and $T_{t}$ remain to be specified but are taken parametrically by the family.

Firms use capital and labor to produce goods and services. Some capital comes from the private sector and some from the government. Output is given by

$$
Y_{t}=F\left(K_{p, t}, K_{g, t}, Z_{t} L_{p, t}\right)
$$

where $K_{p, t}$ is the beginning-of-period private capital stock for the economy in $t, K_{g, t}$ is the beginning-of-period public capital stock used by the private sector in $t, Z_{t}$ is the level of technology in $t$, and $L_{p, t}$ is the total labor input in the private sector in $t$. We assume that technology grows at rate $g_{z}$ and stays on trend through the war, $Z_{t}=z\left(1+g_{z}\right)^{t}$. Braun and McGrattan (1993) find that total factor productivity is roughly at its trend level during the war. (See their Table 3.)

We include government capital in production because the federal government financed large increases in industrial construction and producers' durable equipment during World War II. There were significant increases to the productive capacity of the aircraft, automotive, and aluminum industries. Gordon (1969) estimates that government-owned, privately operated 
capital (GOPO) resulted in a 30 percent increase in manufacturing's capital stock between 1940 and 1945. (See also Jaszi [1970], Gordon [1970], and Wasson et al. [1970].) Braun and McGrattan (1993) use this fact to point out that increases in government investment lead to shifts in the labor demand curve of Figure 1 - thus, providing an alternative story to Rotemberg and Woodford's (1992) countercyclical markups.

We will denote investment spending by the government by $I_{g}$ and consumption spending by $C_{g}$. The period $t$ budget constraint is given by

$$
C_{g t}+I_{g t}+N_{t} T_{t}=\tau_{k t}\left(r_{p t}-\delta\right) K_{p t}+\tau_{l t} w_{t} L_{p t}+r_{g t} K_{g t}
$$

where $r_{g}$ is the rental rate for government capital. Government capital evolves according to

$$
K_{g t+1}=(1-\delta) K_{g t}+I_{g t}
$$

with $K_{g 0}$ and the process for $I_{g t}$ given. Notice that we assume that private and public capital depreciate at the same rate. Here we are assuming that wage payments to soldiers are included in transfers to draftees. Total government spending therefore is given by

$$
G_{t}=C_{g t}+I_{g t}+N_{t} a_{t} w_{t} \bar{l} .
$$

To close the model, we now specify the stochastic processes that the family takes as given when solving its optimization problem in (1). Since firms are competitive, the prices that they pay for factors of production are given by their marginal products. Therefore the rental rates in (2) and (5) and the wage rate in (2) are equal to the partial derivatives of the production function $F$ in (4) with respect to $K_{p}, K_{g}$, and $L_{p}$, respectively. Transfers $T$ are defined residually from the government budget constraint (5); they depend on economy-wide endogenous prices and quantities as well as exogenous government purchases. The processes for 
the draft $a_{t}$, the tax rates $\tau_{l, t}, \tau_{k, t}$, and components of government purchases $C_{g, t}$ and $I_{g, t}$ are assumed to depend on one underlaying state variable, $s_{t}$, which is the "fiscal state." 3 A simple example of the fiscal state is where $s_{t}$ took on two values 'war' or 'peace'. In war, government spending, taxes rates, and the fraction of the population impressed into military service would be high and in peace they would be low. In the next section we describe in detail the fiscal state that we use and the values that $a, \tau_{l}, \tau_{k}, C_{g}, I_{g}$ take.

An equilibrium for this economy is a collection of allocations for households $c_{c, t}, c_{d, t}, l_{c, t}$, $i_{p, t}, k_{p, t}$; allocations for firms $K_{p, t}, L_{p, t}$; and prices $r_{p, t}, r_{g, t}$, and $w_{t}$ that satisfy the following conditions: $(i)$ taking prices and exogenous policies for $a_{t}, \tau_{k, t}, \tau_{l, t}$, and $T_{t}$ as given, households maximize expected utility subject to constraints $(2)-(3) ;(i i)$ taking prices as given, firms period by period maximize profits $Y-r_{p} K_{p}-r_{g} K_{g}-w L_{p} ;(i i i)$ factor markets clear:

$$
\begin{aligned}
K_{p, t} & =N_{t} k_{p, t} \\
L_{p, t} & =N_{t}\left(1-a_{t}\right) l_{c, t}
\end{aligned}
$$

(iv) the resource constraint:

$$
C_{p t}+I_{p t}+C_{g t}+I_{g t}=Y_{t}
$$

holds where $C_{p, t}=N_{t} a_{t} c_{c, t}+N_{t}\left(1-a_{t}\right) c_{d, t}$ and $I_{p, t}=N_{t} i_{p, t}$; and $(v)$ transfers satisfy $(5)$.

Because of our choice of preferences, consumption levels for civilians and draftees will be equated. Below, we use $c_{p, t}$ to denote the per-capita consumption of both types. We will also use the convention that lowercase letters denote per-capita quantities (e.g., $c_{g, t}=C_{g, t} / N_{t}$ ).

\footnotetext{
${ }^{3}$ We actually specify processes for the stationary, per-capita quantities, e.g., $C_{g, t} /\left[\left(1+g_{z}\right)\left(1+g_{n}\right)\right]^{t}$.
} 
We turn now to a comparison of simulations of this model to U.S. aggregate data during the war. We first choose parameters. We then run numerical experiments.

\section{Parameter Values and Exogenous Processes}

Parameters are chosen to roughly equate the steady-state values of variables in the model to the relevant means of the detrended variables in the data. Exogenous processes are modeled as a Markov chain indexed by the state $s$. In state $s$, we observe $c_{g}(s), i_{g}(s), a(s), \tau_{k}(s)$, and $\tau_{l}(s)$. The actual realizations of these series from the data are the shocks in the model.

In all simulations, we assume that a period is one year. Functional forms are chosen to be

$$
\begin{aligned}
V(1-l) & =\psi(1-l)^{\xi} / \xi \\
F\left(k_{p}, k_{g}, z l\right) & =\left(b k_{p}^{\rho}+(1-b) k_{g}^{\rho}\right)^{\frac{\theta}{\rho}}(z l)^{1-\theta}
\end{aligned}
$$

with

$$
\psi=2.3, \xi=0, \theta=0.3, \rho=1, b=1 / 2
$$

in our baseline parameterization. With $\psi=2.3$ and $\xi=0$, preferences are logarithmic and the fraction of time at work is roughly 27 percent - which is the postwar U.S. level. A value of $\theta$ equal to 0.3 is consistent with factor shares reported by Kendrick (1961). The parameters $\rho$ and $b$ govern substitutability and relative productivities of private and public capital. We assume that these two types of capital are perfect substitutes and equally productive.

The rate of depreciation of both types of capital is set equal to $\delta=0.05$. This value is consistent with actual observations on investment and capital stocks. We scale the technology 
$z$ so that output in 1946 is equal to 1 . Growth rates are set to be consistent with U.S. trends, so that $g_{n}=1.6 \%$ and $g_{z}=1.6 \%$. We also scale $\beta$ to guarantee that the postwar capital-output ratio is similar in the model and the data. Finally, the hours for soldiers is set to be $\bar{l}=50 / 84$ which implies that they work 50 out of their 84 discretionary hours per week.

Realizations of the exogenous processes are chosen so that they are exactly in line with their data counterparts. The input series are plotted in Figures 2-4. The nonstationary series, $i_{g}$ and $c_{g}$, have been detrended by $\left(1+g_{z}\right)^{t}$ and scaled by 9,9181982 dollars which is per-capita GNP in 1946 less per-capita military compensation in 1946 (i.e., the equivalent of output in our model). The specific sources and transformations are provided in Appendix A1. In some of the experiments of the next section, we assume that the processes are stochastic. In each case we discuss how the transition matrices were modeled.

In Figure 2, we show the components of government purchases. In 'government investment' we include only part of total government investment during the war. In particular, we include investment relevant to production in the private sector and the civilian government sector. The increase in this series is due primarily to GOPO. 'Government consumption' is treated as a residual; it is given by total spending less government investment and military compensation. A large component of that is increased military equipment. Military equipment is recorded in the National Accounts as investment, but we do not treat it as an input in civilian production.

Figure 3 shows the fraction of the population (16 and over) that is employed by the military. Not surprisingly, the pattern mimics military wages with the peak coming in 1944 . At the peak, 11 percent of the population over the age of 16 was in the army. In Figure 4, we display the tax rates for labor and capital income constructed by Joines 
(1981). This picture clearly shows that there was a large rise in both tax rates. The labor tax rate more than doubled in two years (between 1940 and 1942) and the capital tax rate went from 45 percent to roughly 60 percent. We now turn to assessing the macroeconomic effects of these shocks in our model economy.

\section{Results}

This section compares the model's predictions for hours, consumption, investment, output, wages, and interest rates during World War II with the data. We do this by presenting a graph of the predicted variable from the model with the actual variable.

First, we present the time series of interest. This is done in Figure 5. All trending series have been divided by $\left(1+g_{z}\right)^{t}$ and divided by 9,918 so that output (GNP less military compensation) has a mean of one. The specific number that we use to scale the series will not matter - this is chosen so that consumption and the capital stocks are in interpretable units. In Figure 6, we show the same series for a shorter time horizon: 1941-1950.

Because Rotemberg and Woodford (1991,1992) and Mulligan have focused attention on real wages, we show four different series. Rotemberg and Woodford $(1991,1992)$ use total compensation for civilians divided by the private value added deflator. Here, we use the tax rate of Joines (1981) in Figure 4 to convert it to after-tax. Mulligan uses the wage rate for manufacturing production workers for 25 industries deflated by the CPI and multiplied by the tax rate of Barro and Sahasakul (1986). The first shows a rise in after-tax wages throughout the war and the latter shows a decline. To see what the deflator does, we include civilian wages deflated by the CPI. To see the difference between manufacturing wages and civilian wages, we include both measures (which are both constructed using NIPA data). It is clear that the 
estimates of wages, prices, and tax rates are quite different.

Before presenting the predictions of the model with all the elements included, we first display the theoretical predictions of a stripped down version of the model that Rotemberg (1991, 1992) and Mulligan (1998) critique. This model is the optimal growth model and the predictions are responses to an increase in government purchases.

We then run our main experiments. For these experiments, we include government capital, the draft, and distortionary taxation. The model is parameterized so that with government spending, military wages, and distortionary taxes at levels given by Figures 2-4, the model series have the same means as the data. Thus, we can make a direct comparison of model time series and the data.

In the first experiment, we assume that agents perfectly predict the paths of spending and taxes shown in Figures 2-4. Second, we allow for uncertainty about entering the war and its duration. Third, we assume that rationing was in effect. Fourth, we allow for the possibility of a post-war depression.

In each case, we assume that the initial state in the model is equal to the capital stocks and fiscal state observed in 1941 (i.e., $k_{p, 1941}=1.89$ and $k_{g, 1941}=0.55$ ). Because the economy is just coming out of the Great Depression, we cannot really assume that the the economy is in a steady state in 1940 when comparing model and data. We only start with steady states when describing theoretical impulse responses.

\section{A. Increase Government Spending}

We begin with the most commonly studied case. There is no draft, no productive government spending, government spending is entirely financed with lump sum taxes, and the 
future time path of government expenditures is known with certainty.

We start the simulation from a steady state with $g$ and $c_{g}$ both equal to 0.1635 which is total spending less military wages in 1940 - once we have detrended the data and scaled by output in 1946. (See Figure 2.) At all dates, $i_{g}, a, \tau_{k}$, and $\tau_{l}$ are set equal to 0 . The level of technology, $z$, is set equal to 2.13 in all periods so that output is 1 in 1946 . The steady state capital stocks associated with $g=.1635$ are $k_{p}=4.0$ and $k_{g}=0 .{ }^{4}$ We start the system off in this steady state and feed in the actual government spending shocks once the economy has entered the war.

Figure 7 displays the results of this experiment. The model responses are deviations from the 1940 steady state. Thus, all model responses, except for interest rates, are 0 in 1940. For interest rates we plot the levels. In the model, 1941 is the date of the "shock." In response to the large wealth effect, consumption and leisure fall immediately. Private consumption falls roughly 11 percent and civilian hours of work rise roughly 15 percent. As Figure 1 shows, the shift in the labor supply curve - with the capital stock fixed initially - also implies that wages fall. For our numerical example, the decline in wages (which are not taxed here) is roughly 6 percent by the end of the war.

Now consider the dynamic response of the model - which is not discernible from Figure 1. Once it is known that the country is going to war, interest rates rise and they continue to rise until the end of the war. Investment rises slightly in 1942 but then falls as government spending crowds out private consumption and investment. In this example, it is not high wage rates that drive higher labor input - wage rates are lower. Rather, it is high interest rates that

\footnotetext{
${ }^{4}$ In examples where the tax rates are zero, if we assume that $k_{p}=1.89$ and $k_{g}=.55$ as in the data, then the simulations are dominated by transitions to the zero-tax steady state values.
} 
drive households to work harder. This last prediction is what leads Mulligan (1998) to question neoclassical theory for World War II.

\section{B. Increase Government Defense Spending}

We now want to assume that the increased government spending is primarily increased defense spending as was the case for World War II. We include all components of spending shown in Figure 2, rates of conscription as in Figure 3, and distortionary taxes as in Figure 4. We compare the simulated paths of the model to the actual realizations in Figure $6 .{ }^{5}$

The initial capital stocks are assumed to be equal to $k_{p}=1.89$ and $k_{g}=0.55$ which are the 1941 levels of private and public (non-military) capital, respectively. We assume for now that individuals in 1941 know for certain that they are going to war, and they know the exact path that spending and tax rates will take. After 1950, we assume that inputs do not change from their 1950 levels.

The results of the experiment are displayed in Figure 8. Notice that in the model, hours and output in 1941 are much higher than in the data. This is due to the fact that there is no uncertainty that the United States will be at war in 1942. However, in the remaining years, these series match up well with the data. The percent deviations at the peak of the war from the post-war trends are very similar. On the other hand, the patterns of private consumption in the model and data are quite different. Private consumption in the model is the same as its data counterpart in 1946 but lies above in all other years. The model consumption steadily rises during the war whereas in the data it initially falls for several periods. The capital stock

\footnotetext{
${ }^{5}$ If we look at theoretical impulse responses comparable to those plotted in Figure 7 for the case with distortionary taxes, the responses would be dominated by transitional changes in capital since the tax rates in 1940 are very different from those in 1950.
} 
in the model and data are set equal in 1941. Both fall during the war and then rise. In the model, however, there is a significant rise in investment initially. After-tax real wages in the model display a similar pattern to those for manufacturing and both are below their trends throughout the decade. The real interest rate in the model is above its trend level of roughly 2.83 percent and increases to 4.33 percent. This is much higher than Barro's (1987) average estimate of -0.1 percent. We see later that expectations will play an important role for this picture. Mulligan's critique of neoclassical theory also emerges in this example - high labor input is associated with high interest rates.

\section{Add Uncertainty About Entering the War and its Duration}

So far we have assumed that individuals had perfect foresight and therefore knew the path for the fiscal variables. We now introduce uncertainty about the fiscal state. We first assume that there is some uncertainty about entering and ending the war. We will see that this uncertainty dampens the initial responses and leads to roughly constant real interest rates. The real interest rates, however, are on average high. Therefore, we consider introducing rationing which has a negative effect on marginal rates of substitution and therefore on real interest rates. We also introduce uncertainty about a post-war depression which has the effect of dampening interest rates.

Suppose that individuals do not know with certainty that they will enter the war in 1942. Assume, for example, that the probability is in fact only 10 percent that they go to war in 1942. Once at war, they know with certainty what the path of taxes and spending will be during the war. Suppose, in addition, that there is uncertainty about when the war will end.

In Figure 9, we display transition probabilities for the case we consider. In 1941, there 
is a 10 percent chance that the war begins right away. During the war years, three things are possible: staying at current levels of spending and taxes, transiting to the next stage of the war, or ending the war. The solid line is the path that is actually realized - thus, during the war they observe levels of spending and taxes consistent with U.S. levels. However, since there is some probability of staying at current levels or ending the war altogether, the duration of the war is uncertain.

Government spending in 1945 was close to its peak wartime level, the fraction in the military were high, and tax rates were high. (See Figure 2.) If the end of the war is declared, then individuals put a high probability on transiting to the post-war trend (the 1950 levels of spending and taxes) and a low probability on the particular transition path that was actually observed. This choice captures the fact that individuals know roughly what to expect for postwar levels of spending and taxes but not exactly. As before, the solid line in Figure 9 is the path actually taken in the simulation.

In Figure 10 we display the results of the first experiment with uncertainty. In this case, we assume during the war that there is a 10 percent chance of staying at current levels of spending, a 80 percent chance of transiting to the next stage, and a 10 percent chance of the war ending. This is close to the extreme assumption of perfect foresight during the war. Notice that uncertainty in 1941 leads to a smaller increase in hours and GNP and smaller decreases in consumption and investment. The less likely it is that we transit to the state with spending and taxes at 1942 U.S. levels, the smaller are the changes in these variables. With hours now rising between 1941 and 1942, there is a larger decline in after-tax real wages.

Notice that with uncertainty about the duration of the war, the interest rates do not jump up as much and consumption does somewhat better in fitting the pattern actually observed. 
The only real failure of the model is its implications for the level of the real interest rates. Because nominal interest rates were very low during World War II, most estimates of real interest rates are near zero. Mulligan's critique still remains.

\section{Add Rationing}

During the war, goods were rationed. In our previous simulation we found that while consumption fell slightly, it did not fall as much as U.S. private consumption. Also, the model predicts high real interest rates during the war while most historians estimate that the real interest rate was low. If we add rationing to the model, we can possibly correct both failings of the model. Rationing leads to lower consumption, expectations of lower growth rates of consumption, and therefore lower real interest rates.

Consider adding the following constraints to the problem of a typical family in (1):

$$
\begin{aligned}
c_{c, t} & \leq c_{\max }\left(s_{t}\right) \\
c_{d, t} & \leq c_{\max }\left(s_{t}\right)
\end{aligned}
$$

where $c_{\text {max }}\left(s_{t}\right)$ is an upper bound on consumption that depends on the fiscal state. So, for example, in war $c_{\max }$ may be low and in peace it would be high (and the constraint would not be binding). For experiment 4, we assume that constraints were binding during the war which implies that $c_{\max }$ during 1942-1945 was equal to observed levels of consumption. (See Figure $6)$.

The results of the simulation are displayed in Figure 11. A comparison of Figures 10 and 11 show that the only significant effects of rationing are in the patterns of private consumption and real interest rates. While we do get a significant decline in the real interest rate during the 
war - roughly 1 percentage point - the rate is still high relative to estimates on bond yields for the United States. To address Mulligan's criticism, we want to have after-tax wage rates and the real interest rate below its trend level with hours of work above its trend level.

\section{E. A Check on Sensitivity}

As a check on the sensitivity of our results to choices of transition probabilities, we redo experiments 3 and 4 using a higher probability of staying at current levels of spending and taxes.

In Figures 12 and 13, we report results for these simulations. In these cases, we assume during the war that there is a 50 percent chance of staying at current levels of spending, a 25 percent chance of transiting to the next stage, and a 25 percent chance of the war ending. (Recall that Figures 10 and 11 used 10, 80, and 10 respectively.) Figure 12 is the case without rationing and Figure 13 is the case with rationing. Although there are some differences in the results (Figure 10 versus 12 and Figure 11 versus 13), they are quantitatively small.

\section{F. Add the Possibility of a Post-war Depression}

We now consider adding the following constraint on hours of work:

$$
l_{c, t} \leq l_{\max }\left(s_{t}\right)
$$

This constraint is intended to capture the fact that in some states of the world, it is difficult to increase hours of work. During the depression, employment and hours were very low and many people had trouble finding work. If agents in our model fear that the economy might fall into a post-war depression, they increase their saving and increase their hours even if real interest rates are low. 
The transition matrix is assumed to be the same as in experiments 5 and 6 . The only difference is that agents think that they will enter a post-war depression when the war ends. This state is never realized but does affect expectations. If the state were realized, agents expect that their hours of work would be at most 80 percent of normal levels - as was true in the Great Depression. Thus, we choose $l_{\text {max }}$ to be 80 percent of 0.27 if the 'depression state' is realized.

When we run this experiment we find that all series match up well - except for hours. Hours of work are too high relative to the data even with a lower than average after-tax wage rate and and a lower than average real interest rate. As a result, we make one more change: we decrease the elasticity of labor by lowering $\xi$ from 0 to -0.7 . We also lower $\psi$ from 2.3 to 1.9 so as to achieve a postwar trend in hours of 27 percent. The results for the case with no rationing are displayed in Figure 14.

Overall, the fit in Figure 14 is remarkable given the simplicity of the model. In both the model and the data, GNP and hours are up roughly 40 percent above their postwar levels. In both the model and the data, consumption falls initially, stays low, and then recovers. The model still predicts too much initial investment relative to the data but the fit is much better than in our earlier simulations. After-tax real wages in the model fall about as much wages in U.S. manufacturing. Interest rates fall and stay down throughout the war. In this simulation, the trend rate is 3.57 percent. Thus, both after-tax real wages and real interest rates are below trend and still we see hours rising 40 percent.

For the simulation of Figure 15, we keep all parameters the same except that we impose rationing during the war. This implies a better fit of consumption but similar results for all other variables. As in the case with no rationing, we find hours significantly above trend despite 
the fact that real interest rates and wage rates are below trend levels. This final case makes significant progress in meeting the challenge set out by Mulligan.

\section{Conclusion}

The large World War II economic expansion has long puzzled economists and historians. Previous studies of World War II (Barro, Braun and McGrattan, and Ohanian) have shown that neoclassical theory could account for wartime economic performance, but required either large increases in after-tax wage rates and/or interest rates. Since there is little evidence of these increases, some researchers have concluded that significant departures from standard theory, such as preference shocks in the form of patriotism, or time-varying mark-ups, are required to understand economic activity during this period. Our results show that this conclusion is premature. Introducing plausible features into the standard model - uncertainty over the duration of the war, rationing, and fear of a post-war depression - allows the neoclassical model to account for World War II economic performance.

In particular, the model predicts a large increase in hours worked during the war and predicts decreases in low after-tax wages and interest rates. In contrast to the conventional wisdom, we conclude that there is no obvious need to incorporate imperfect competition (Rotemberg and Woodford 1991,1992) or patriotism (Mulligan 1998) to understand the U.S. economy during World War II. 


\section{Appendix}

\section{A1. Exogenous Processes}

The following series are taken as inputs for the numerical simulations reported in Section 5.

Per-capita Government Purchases in $1982 \$(g)$

- Sources:

1. NIPA of the US, 1929-82, Tables 1.2, for purchases

2. Historical Statistics, Series A39, for population over 16

- Transformations:

1. Per-capita purchases: use NIPA Table 1.2 purchases and divide by population over 16

Per-capita Non-military Government Investment in $1982 \$\left(i_{g}\right)$

- Sources:

1. Fixed Reproducible Tangible Wealth in the U.S., 1925-85 for investment

2. Historical Statistics, Series A39, for population over 16

- Transformations:

1. Government investment: subtract military equipment and half of military facilities from total federal plus state and local investment

2. Per-capita: divide investment by population over 16

Per-capita Military Compensation in $1982 \$(a w \bar{l})$

- Sources:

1. Historical Statistics, Series F167, for military wages

2. Historical Statistics, Series A39, for population over 16

3. NIPA of the US, 1929-82, Tables 3.7A, and 3.8A

- Transformations:

1. Real compensation: series F167 is converted to real by using the deflator for compensation of federal employees (from NIPA Tables 3.7A and 3.8A)

2. Per-capita: divide real compensation by population over 16

Per-capita Government Consumption in $1982 \$\left(c_{g}=g-i_{g}-a w \bar{l}\right)$

Tax Rates $\left(\tau_{k}, \tau_{l}\right)$ 
- Source: Joines 1981, series MTRK1 and MTRL1

- Transformation: None

Fraction of Population in Military $(a)$

- Sources:

1. Kendrick 1961, Table A-VI, Persons engaged in military

2. Historical Statistics, Series A39, for population over 16

- Transformation: divide employees by population over 16

\section{A2. U.S. Time Series}

The following U.S. time series are compared to the model simulations of Section 5.

Per-capita GNP in $1982 \$\left(c_{p}+i_{p}+g\right)$

- Sources:

1. NIPA of the US, 1929-82, Table 1.2, for GNP

2. Historical Statistics, Series A39, for population over 16

- Transformation: divide GNP by population over 16

Per-capita Private Consumption in $1982 \$\left(c_{p}\right)$

- Sources:

1. NIPA of the US, 1929-82, Table 1.2, for personal consumption

2. Historical Statistics, Series A39, for population over 16

- Transformation: divide consumption by population over 16

Per-capita Total Hours of Work $\left(l_{p}+a \bar{l}\right)$

- Sources:

1. Kendrick 1961, Table A-VI, Manhours for National economy

2. Historical Statistics, Series A39, for population over 16

- Transformation:

1. Fraction of time: divide annual manhours by total discretionary time assumed to be 4368 hours ( 52 weeks $\times 84$ hours per week) 
Per-capita Civilian Hours of Work $\left(l_{p}\right)$

- Sources:

1. Kendrick 1961, Table A-VI, Manhours

2. Historical Statistics, Series A39, for population over 16

- Transformations:

1. Civilian manhours: subtract military manhours from those for national economy

2. Fraction of time: divide annual manhours by total discretionary time as above

Per-capita Private Capital Stock in $1982 \$\left(k_{p}\right)$

- Sources:

1. Historical Statistics, Series A39, for population over 16

2. Fixed Reproducible Tangible Wealth in the U.S., 1925-85 for capital stocks

- Transformations:

1. Private capital: constant-cost net stock of fixed private capital

2. Per-capita: divide by population over 16

Per-capita Public, Non-military Capital Stock in $1982 \$\left(k_{g}\right)$

- Sources:

1. Historical Statistics, Series A39, for population over 16

2. Fixed Reproducible Tangible Wealth in the U.S., 1925-85 for capital stocks

- Transformations:

1. Non-military capital: constant-cost net stock of fixed public capital less military equipment and less one-half of military facilities

2. Per-capita: divide by population over 16

Per-capita Total Capital Stock in $1982 \$\left(k_{p}+k_{g}+k_{m}\right)$

- Sources:

1. Historical Statistics, Series A39, for population over 16

2. Fixed Reproducible Tangible Wealth in the U.S., 1925-85 for capital stocks

- Transformations:

1. Total capital: constant-cost net stock of fixed private capital plus total governmentowned capital

2. Per-capita: divide by population over 16

After-tax Real Wage -Series $1\left(\left(1-\tau_{l}\right) w\right)$ 
- Sources:

1. Historical Statistics, Series D802, D803 for wages

2. NIPA of the US, 1929-82, Table 7.4 for deflator

3. Joines 1981 for tax rate

- Transformations:

1. Wage rate: Divide average weekly earnings in manufacturing by average weekly hours

2. Real wage: divide this wage rate by the GNP price deflator

3. After-tax: multiply by 1 - the tax rate

After-tax Real Wage -Series $2\left(\left(1-\tau_{l}\right) w\right)$

- Sources:

1. Economic Report of the President 1988, Table B-24 for wages

2. Historical Statistics, Series F167 for military wages

3. Historical Statistics, Series E135 for all-items CPI

4. Joines 1981 for tax rate

- Transformations:

1. Total wages: add total wages and salaries to total supplements to w\&s

2. Non-military: subtract military wages

3. Wage rate: divide by manhours of national economy less those for the military

4. Real wage: divide this wage rate by the CPI

5. After-tax: multiply by $1-$ the tax rate 


\section{References}

Aiyagari, Rao, Lawrence Christiano, and Martin Eichenbaum. 1992. The output, employment, and interest rate effects of government consumption. Journal of Monetary Economics 30: 73-86.

Blanchard, Olivier and Roberto Perotti. 1999. An empirical characterization of the dynamic effects of changes in government spending and taxes on output NBER working paper, 7269.

Barro, Robert J. 1981. Output effects of government purchases. Journal of Political Economy 89:1086-1121.

Barro, Robert J. 1987. Macroeconomics, Second Edition. New York, NY: John Wiley and Sons.

Barro, Robert J. and Chaipat Sahasakul. 1986. Average Marginal Tax Rates from Social Security and the Individual Income Tax. Journal of Business 56:419-452.

*Baxter, Marianne, and Robert G. King. 1993. Fiscal policy in general equilibrium. American Economic Review 83(3): 315-334.

Braun R. Anton and Ellen R. McGrattan The macroeconomics of war and peace, In NBER macroeconomics annual 1993. Cambridge: MIT Press.

Edelberg, Wendy, Martin Eichenbaum, and Jonas Fisher. 1999. Understanding the effects of a shock to government purchases, mimeo, Northwestern University.

Fatas, A. and I. Mihov. 1998. Measuring the effects of fiscal policy, mimeo, INSEAD.

Gordon, Robert J. 1969. $\$ 45$ billion of U.S. private investment has been mislaid. American Economic Review 59: 221-238.

Gordon, Robert J. 1970. Communications: $\$ 45$ billion of U.S. private investment has been mislaid: Reply. American Economic Review 60: 940-945.

Hall, Robert E. 1980. Labor supply and aggregate fluctuations. Carnegie- Rochester Series on Public Policy 12: xx-xx.

*Homer, Sidney, and Richard Sylla. 1991. A History of Interest Rates, 3rd edition. New Brunswick: Rutgers University Press.

Jaszi, George. 1970. Communications: $\$ 45$ billion of U.S. private investment has been mislaid: Comment. American Economic Review, 60: 934-939.

Joines, Douglas. 1981. Estimates of effective marginal tax rates on factor incomes. Journal of Business 54:191-226.

Kendrick, John W. 1961. Productivity Trends in the United States. Princeton, NJ: Princeton University Press.

Mulligan, Casey. 1998. Pecuniary incentives to work in the United States during World War II. Journal of Political Economy. 106(5): 1033-77. 
Ohanian, Lee E. 1997. The macroeconomic effects of war finance in the United States: World War II and the Korean War. American Economic Review 87: 23-40.

Ramey, Valerie, and Matthew Shapiro. 1997. Costly capital reallocation and the effects of government spending. Carnegie-Rochester Conference Series on Public Policy.

Rockoff, Hugh. 1984. Drastic Measures: A History of Wage and Price Controls in the United States. Cambridge: Cambridge University Press.

Rotemberg, Julio J., and Michael Woodford. 1991. Markups and the business cycle. In NBER Macroeconomics Annual 1991, Cambridge: MIT Press.

Rotemberg, Julio J., and Michael Woodford. 1992. Oligopolistic pricing and the effects of aggregate demand on economy activity. Journal of Political Economy. 100(6): 1153-1207.

U.S. Department of Commerce. Bureau of Economic Analysis. 1987. Fixed Reproducible Tangible Wealth in the U.S., 1925-85. Washington DC: U.S. Government Printing Office.

U.S. Department of Commerce. Bureau of the Census. 1975. Historical Statistics of the United States, Colonial times to 1970. Bicentennial ed., Part 2. Washington, D.C.: U.S. Government Printing Office.

U.S. Department of Commerce. Bureau of Economic Analysis. 1986. The National Income and Product Accounts of the United States, 1929-82. Washington, D.C.: U.S. Government Printing Office.

U.S. Economic Report of the President. 1988. Washington DC: U.S. Government Printing Office.

Wasson, Robert C., John C. Musgrave, and Claudia Harkins. 1970. Alternative estimates of fixed business capital in the U.S., 1925-68. Survey of Current Business 4:18-36. Washington DC: U.S. Government Printing Office. 
Rotemberg and Woodford 1991,1992.

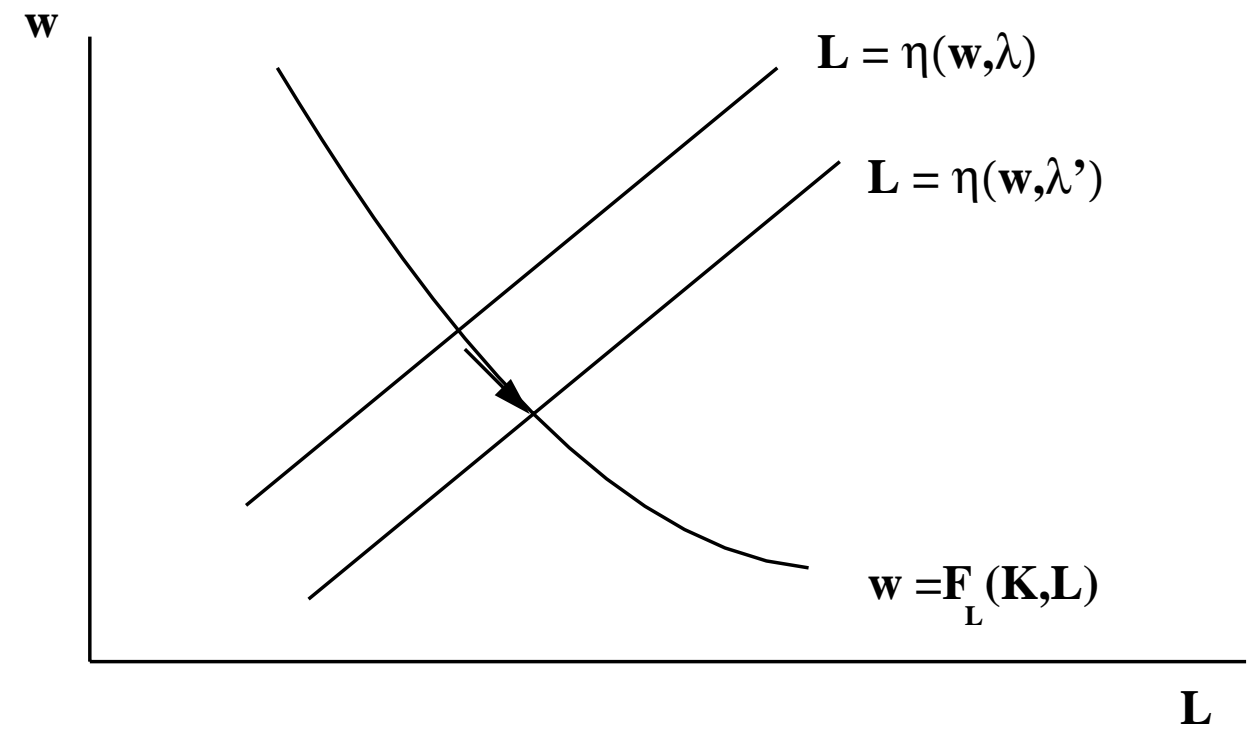

Mulligan 1998.

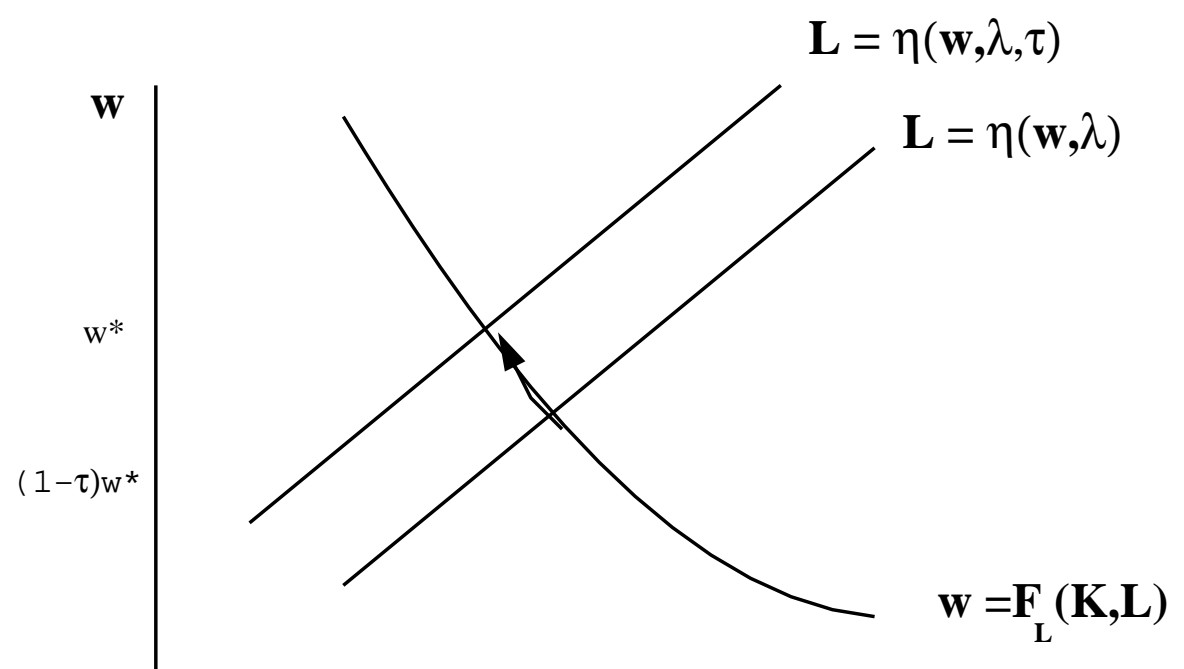

$\mathbf{L}$

Figure 1. Critiques of Standard Competitive Theory. 


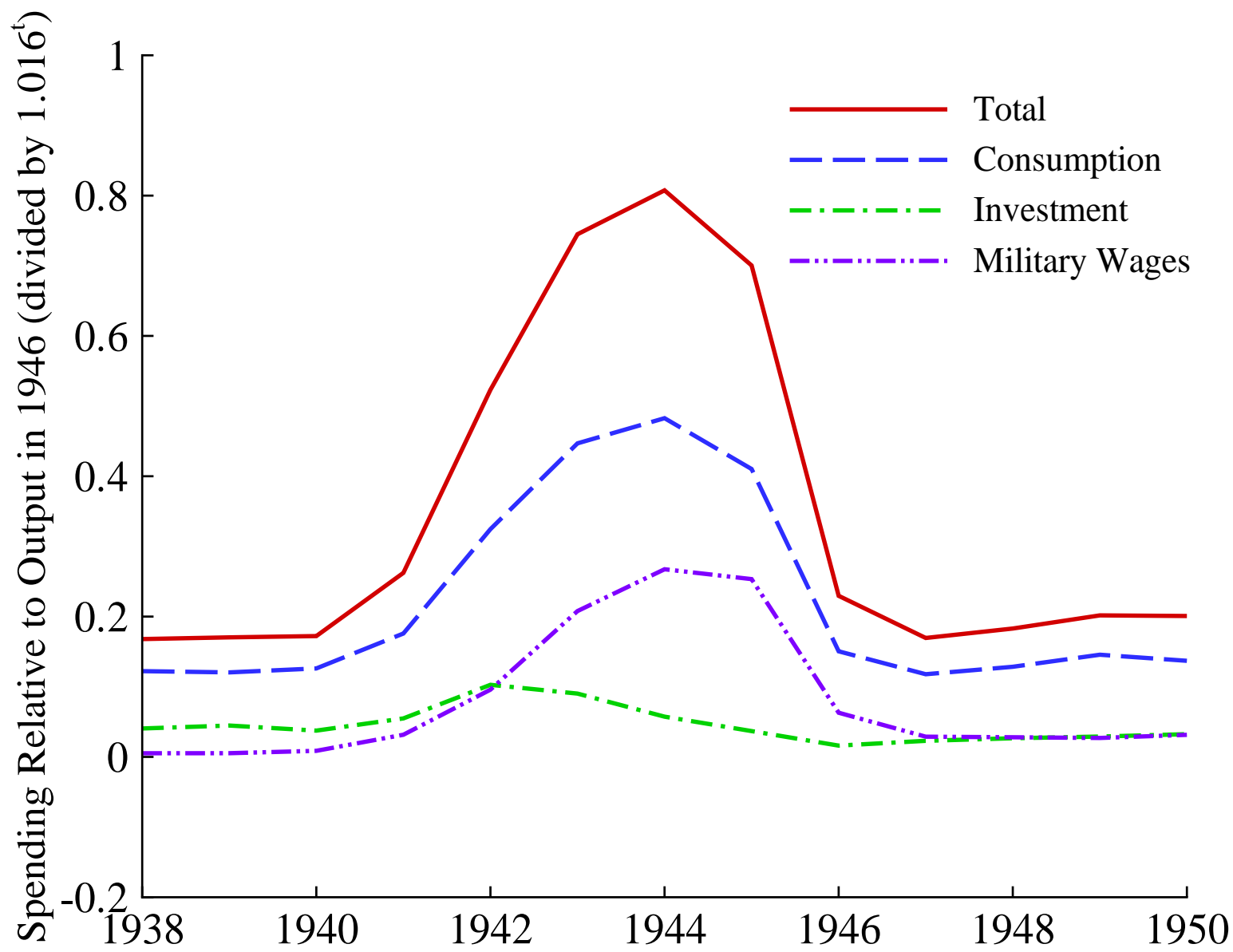

Figure 2. Components of U.S. Government Spending. 


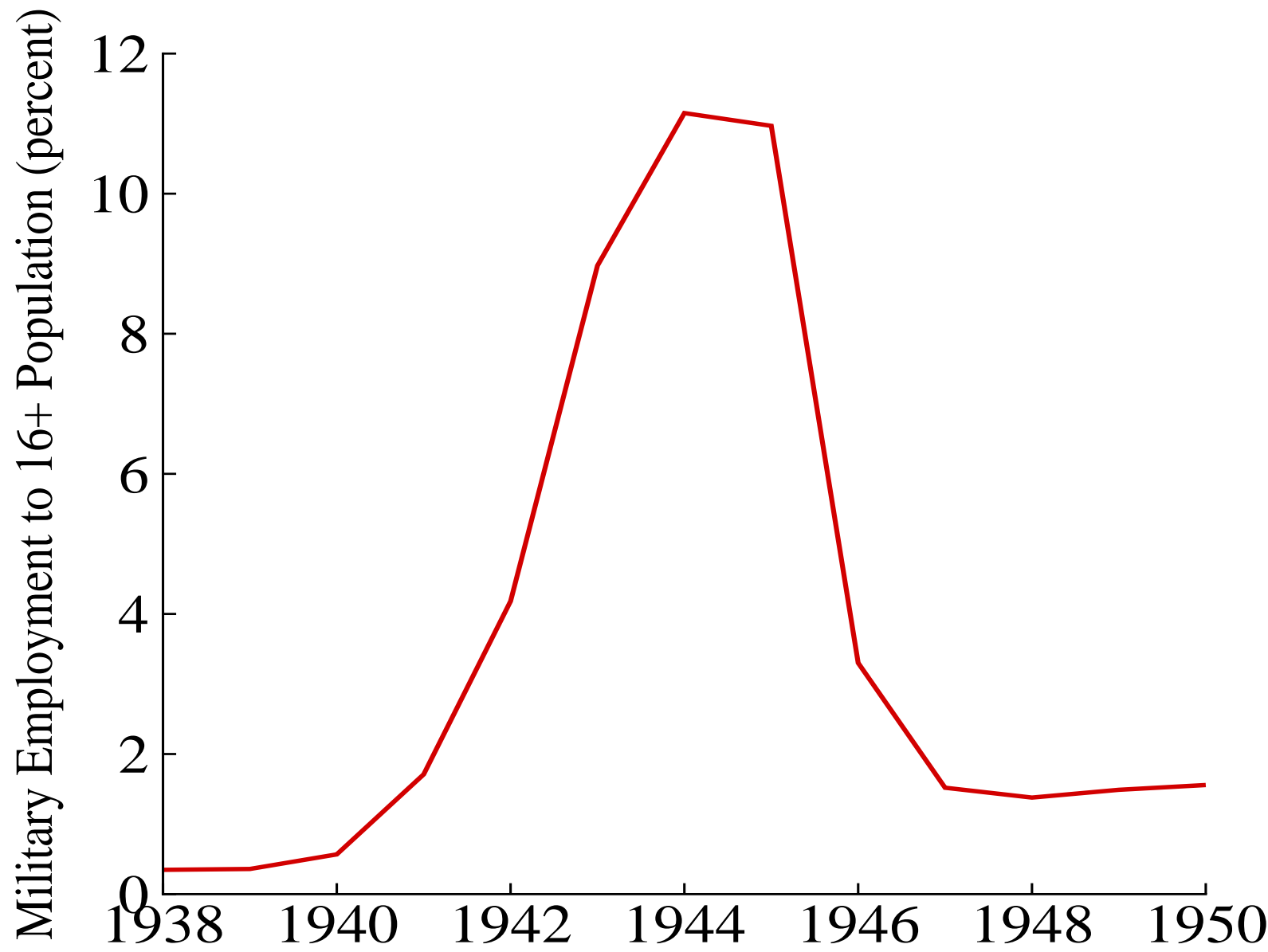

Figure 3. Fraction of U.S. Population over 16 in the Military. 

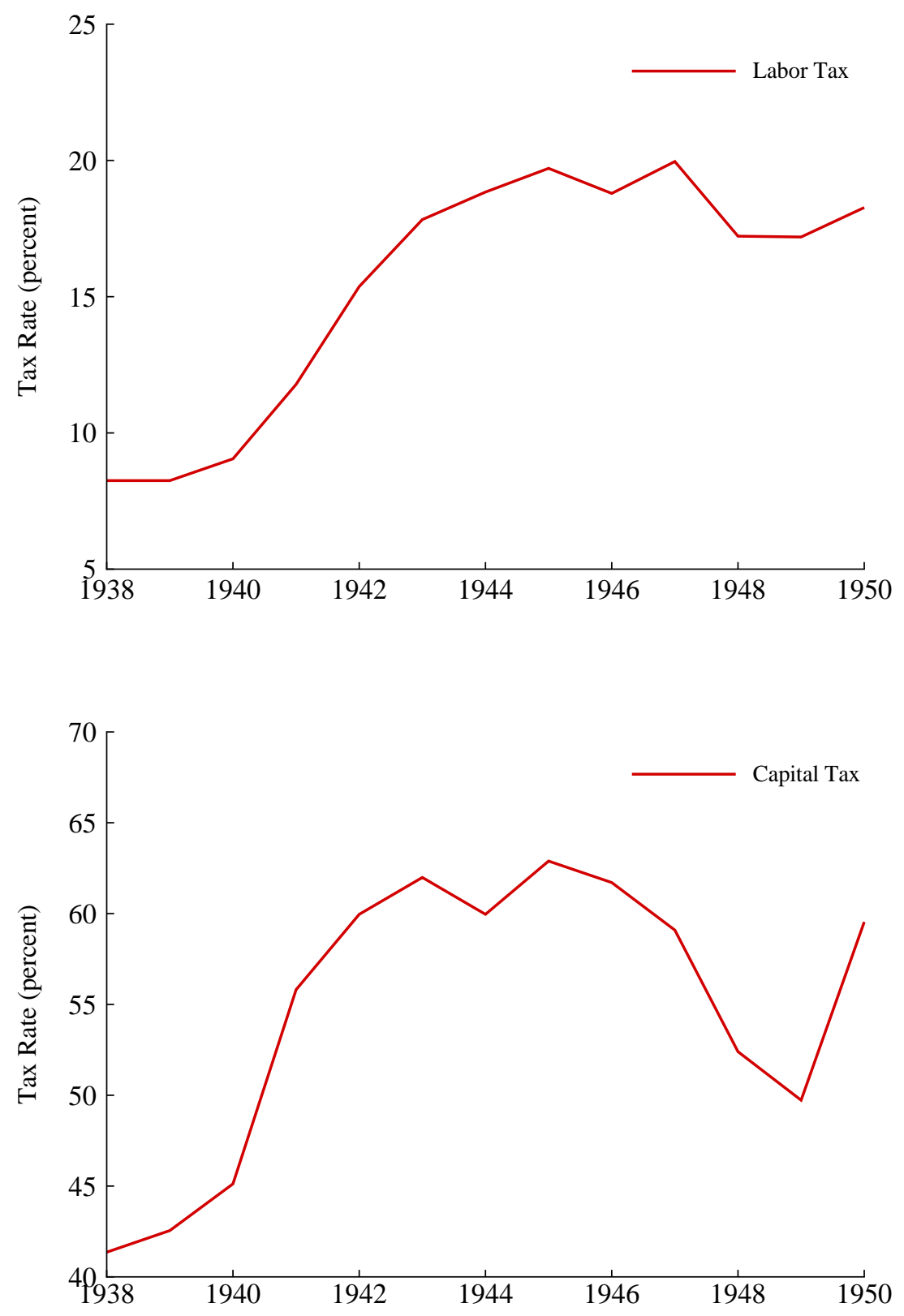

Figure 4. Effective U.S. Tax Rates. 

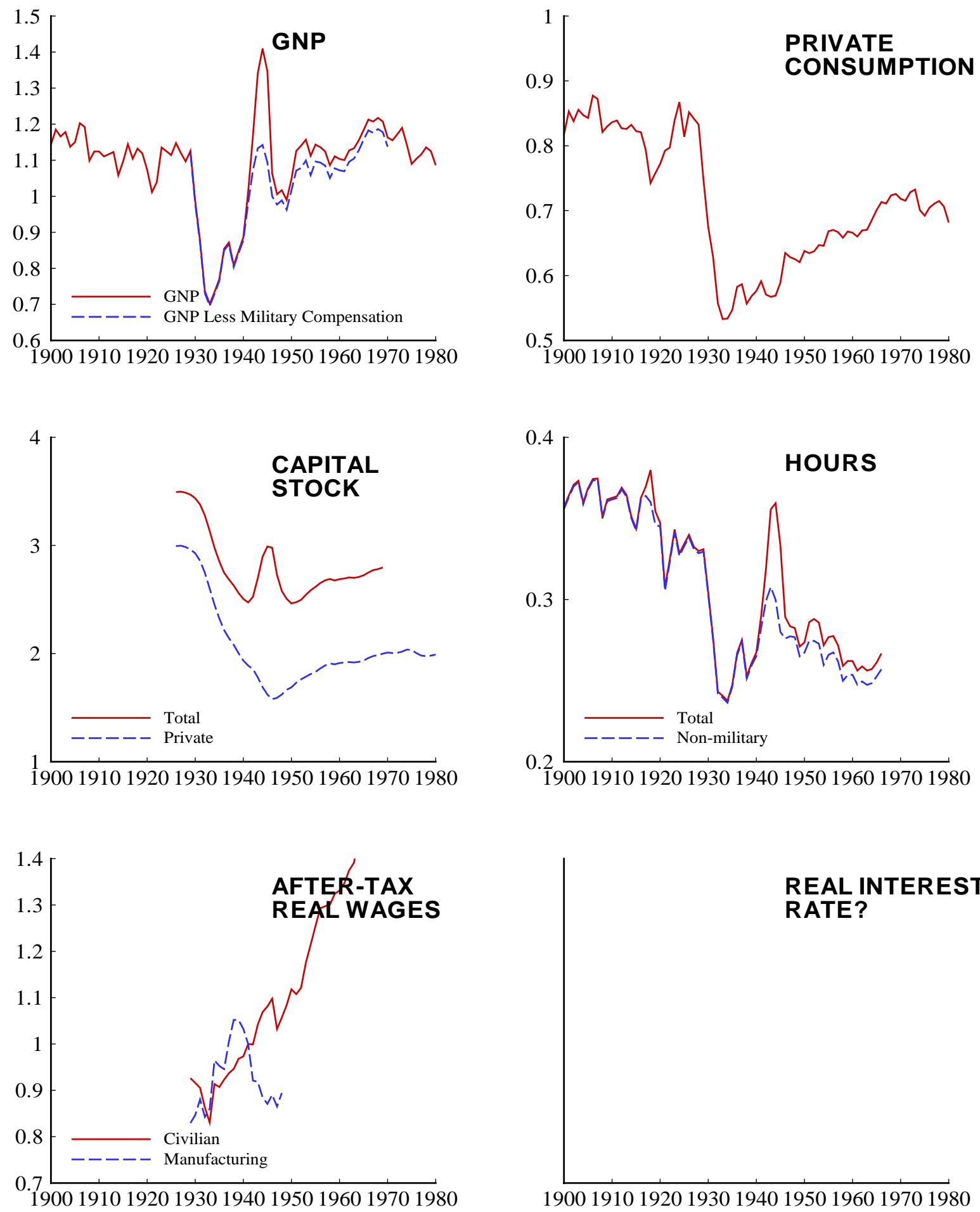

REAL INTEREST RATE?

Figure 5. U.S. Time Series, 1900-1980 (scaled and detrended). 

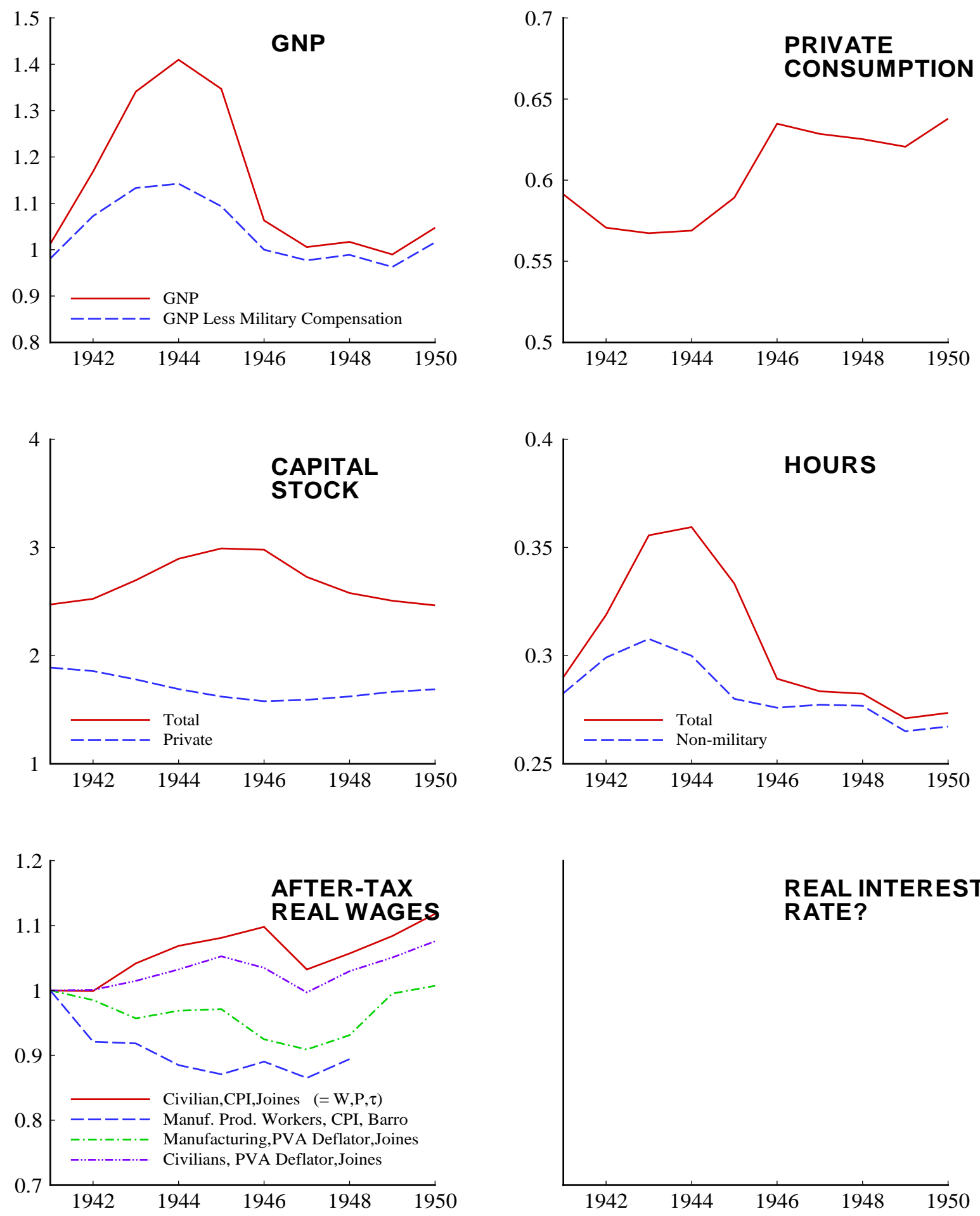

Figure 6. U.S. Time Series, 1941-1950 (scaled and detrended). 

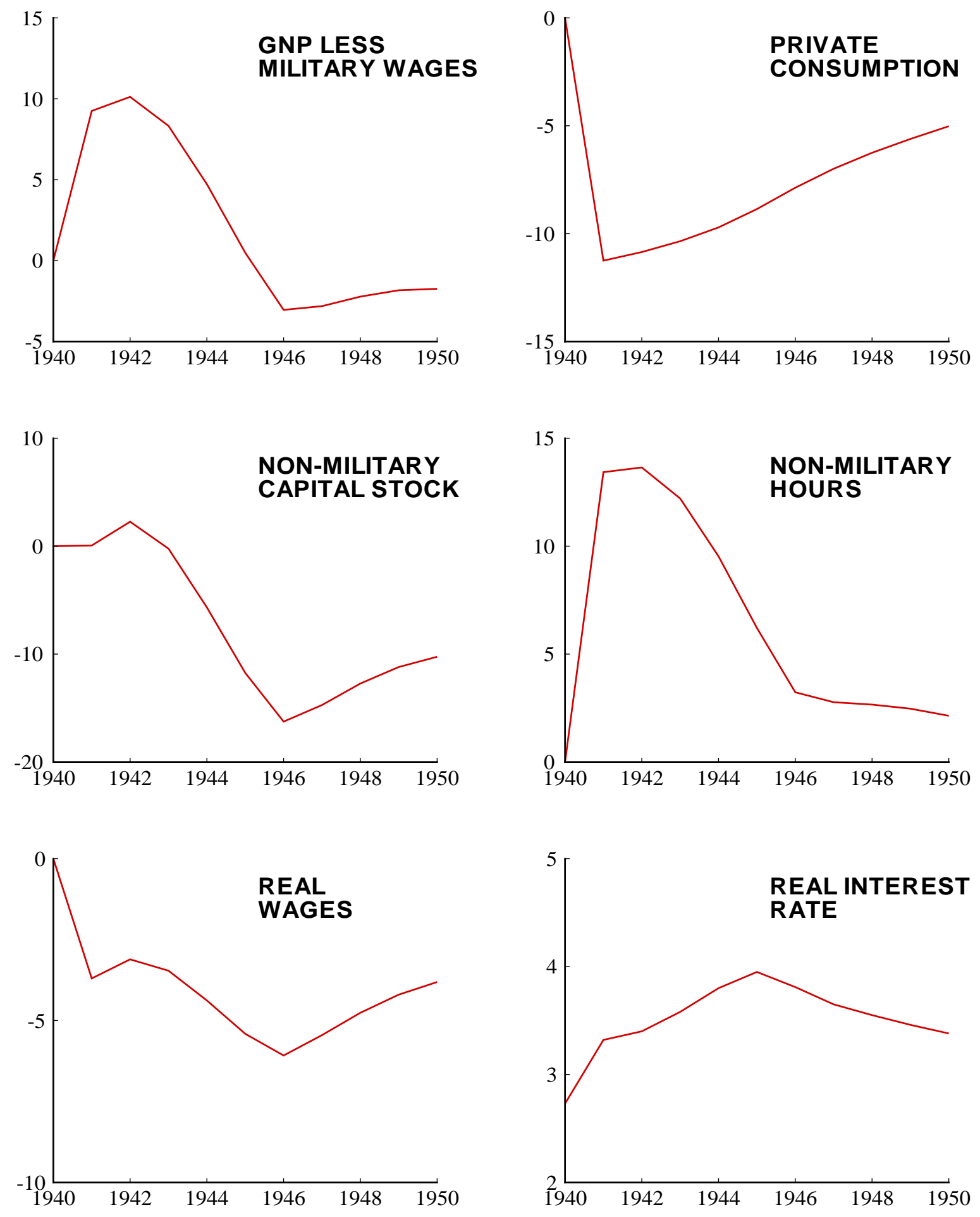

Figure 7. Responses to Increase in Government Nondefense Spending (all in percent deviations except for the interest rate). 

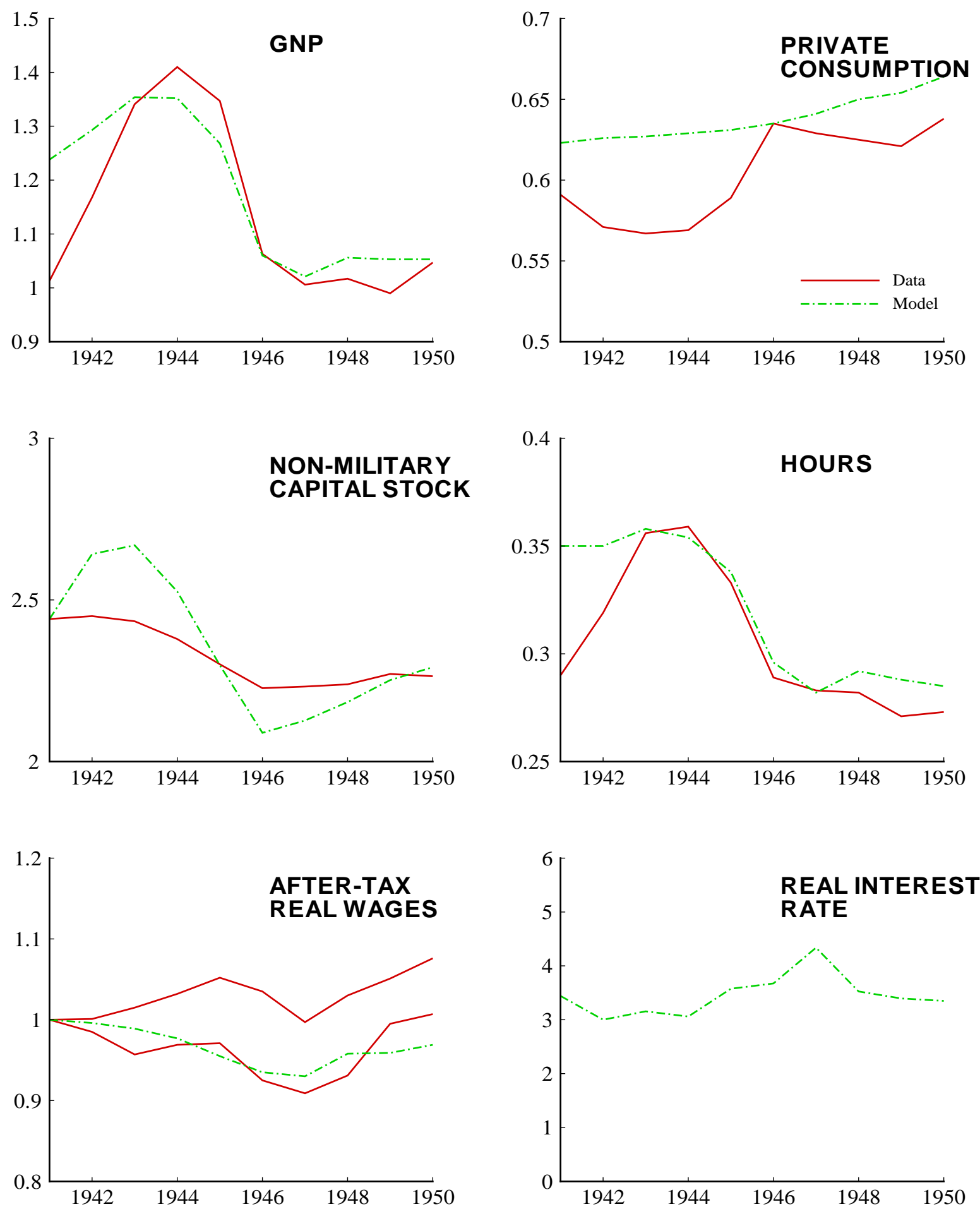

Figure 8. U.S. Time Series and Perfect Foresight Simulation (Experiment 2). 


\section{Exogenous States}

Initial conditions: Capital stocks, spending \& taxes at 1941 US levels

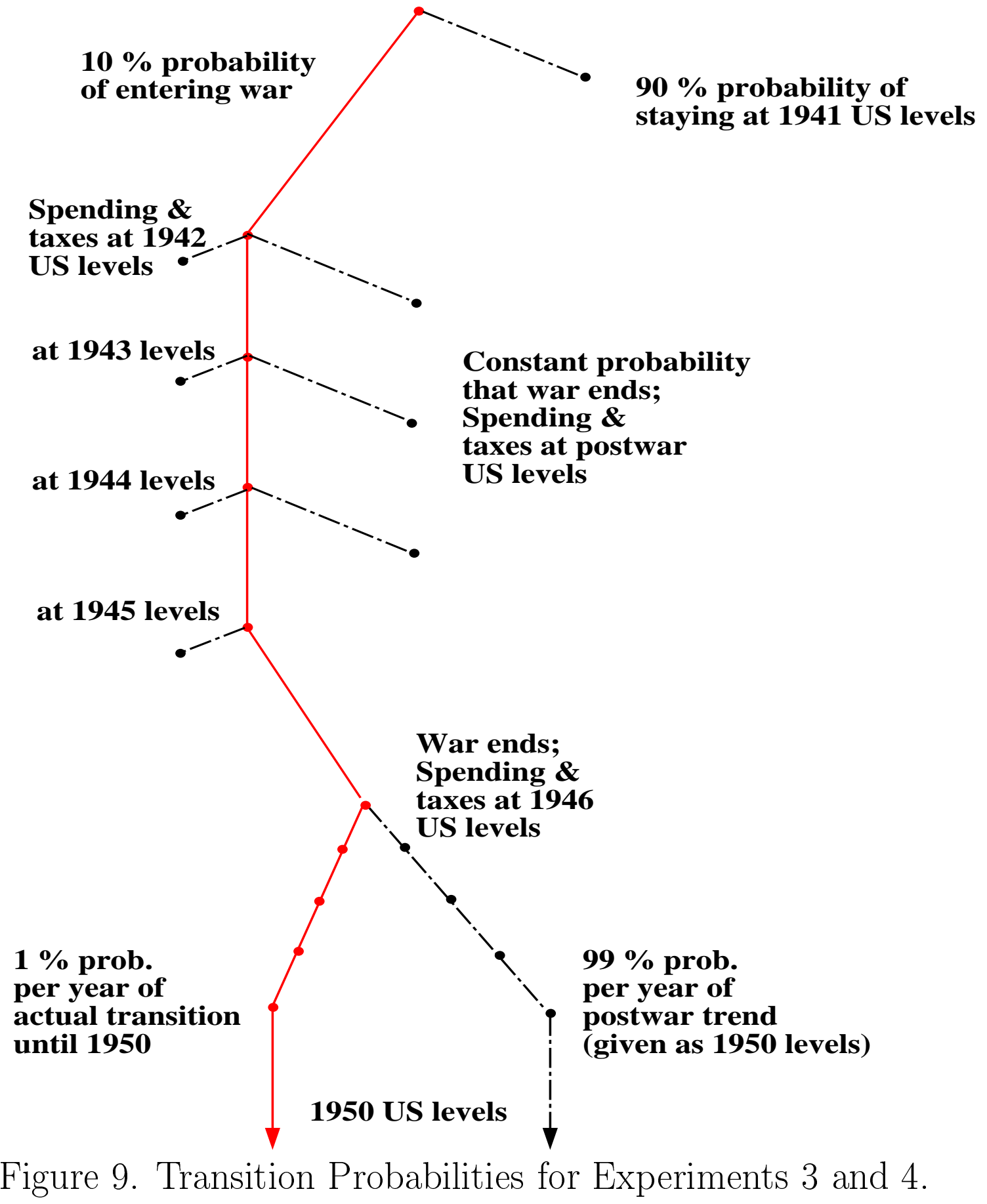



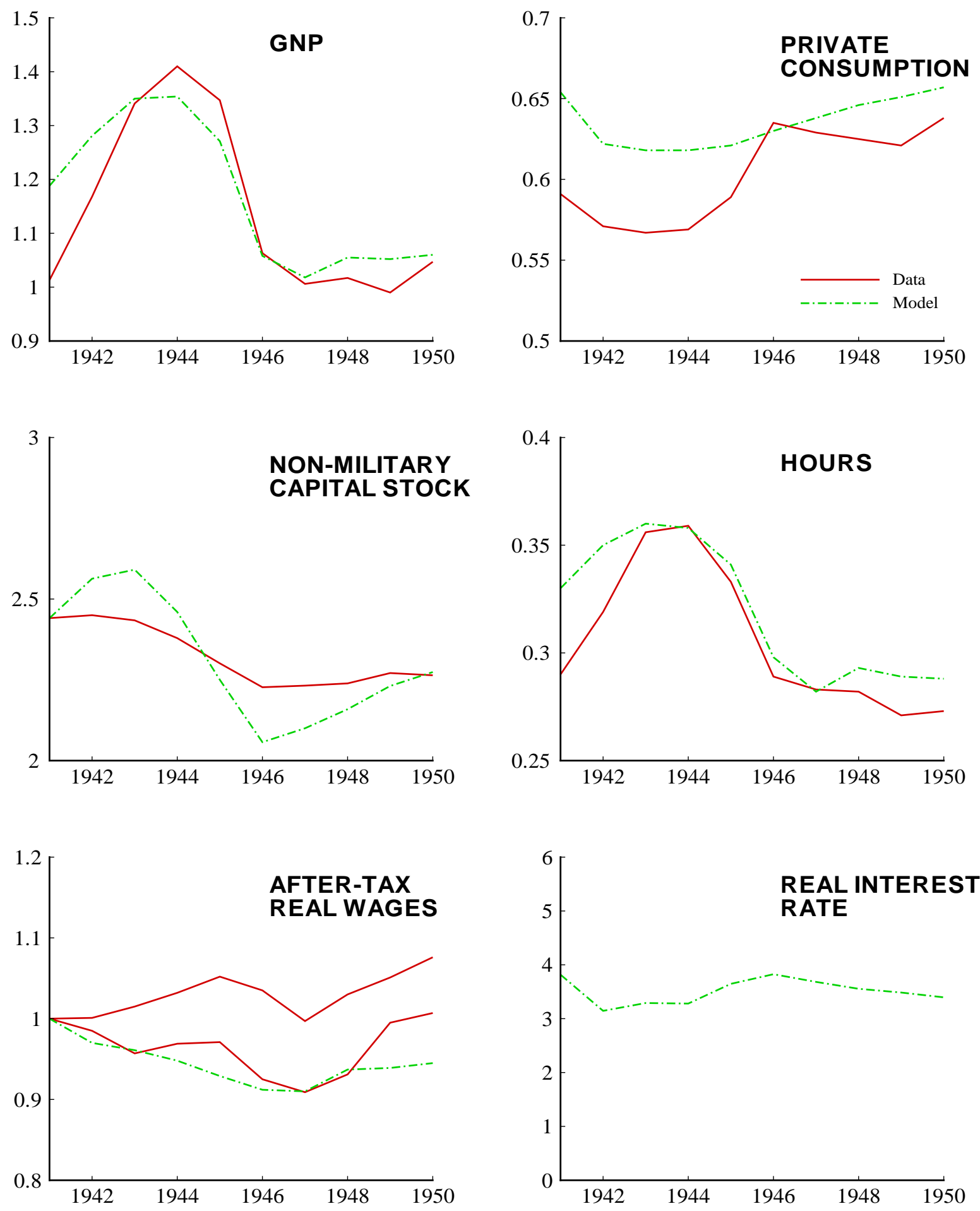

Figure 10. U.S. Time Series and Model Simulation with Uncertainty (Experiment 3). 

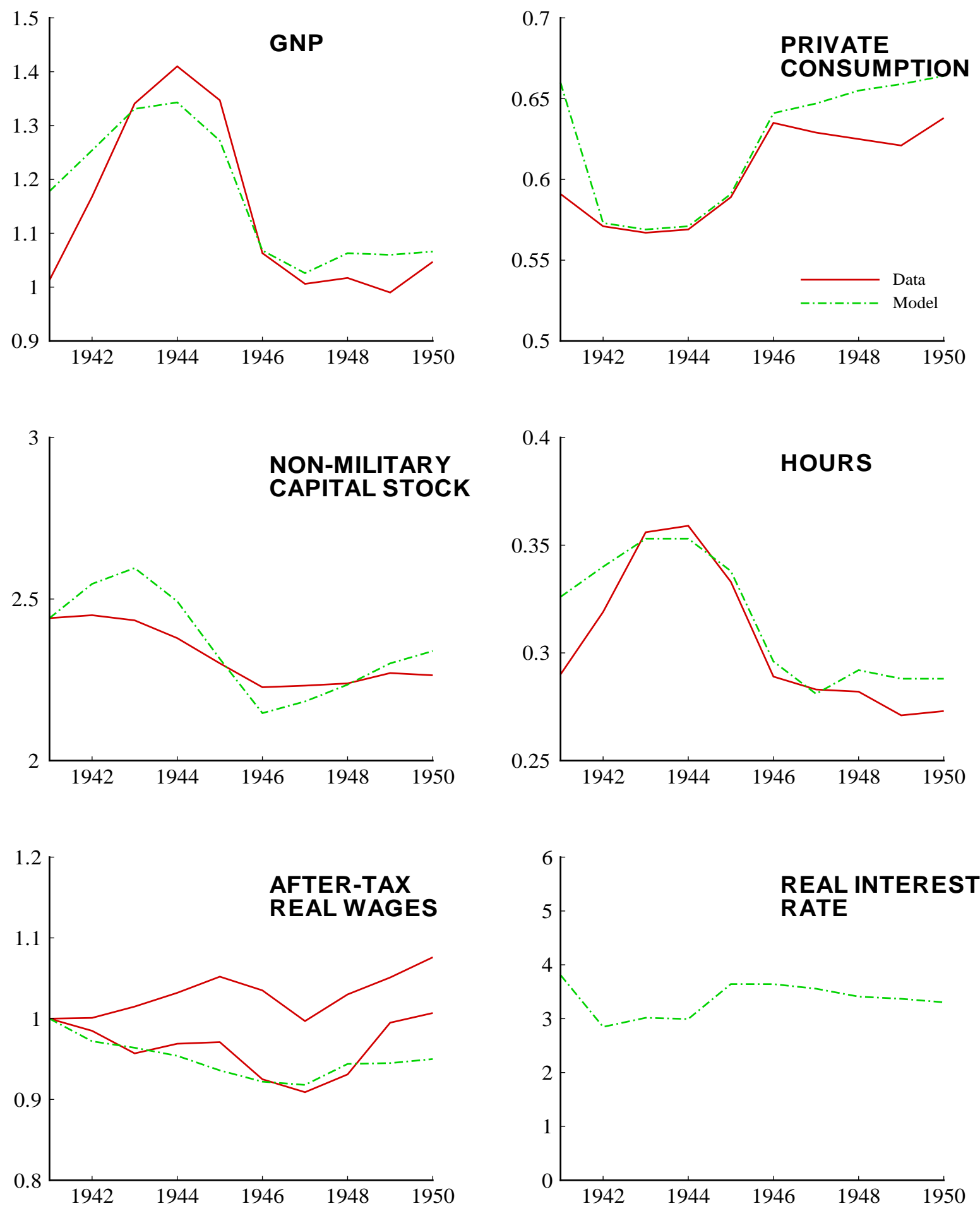

Figure 11. U.S. Time Series and Model Simulation with Uncertainty and Rationing (Experiment 4). 

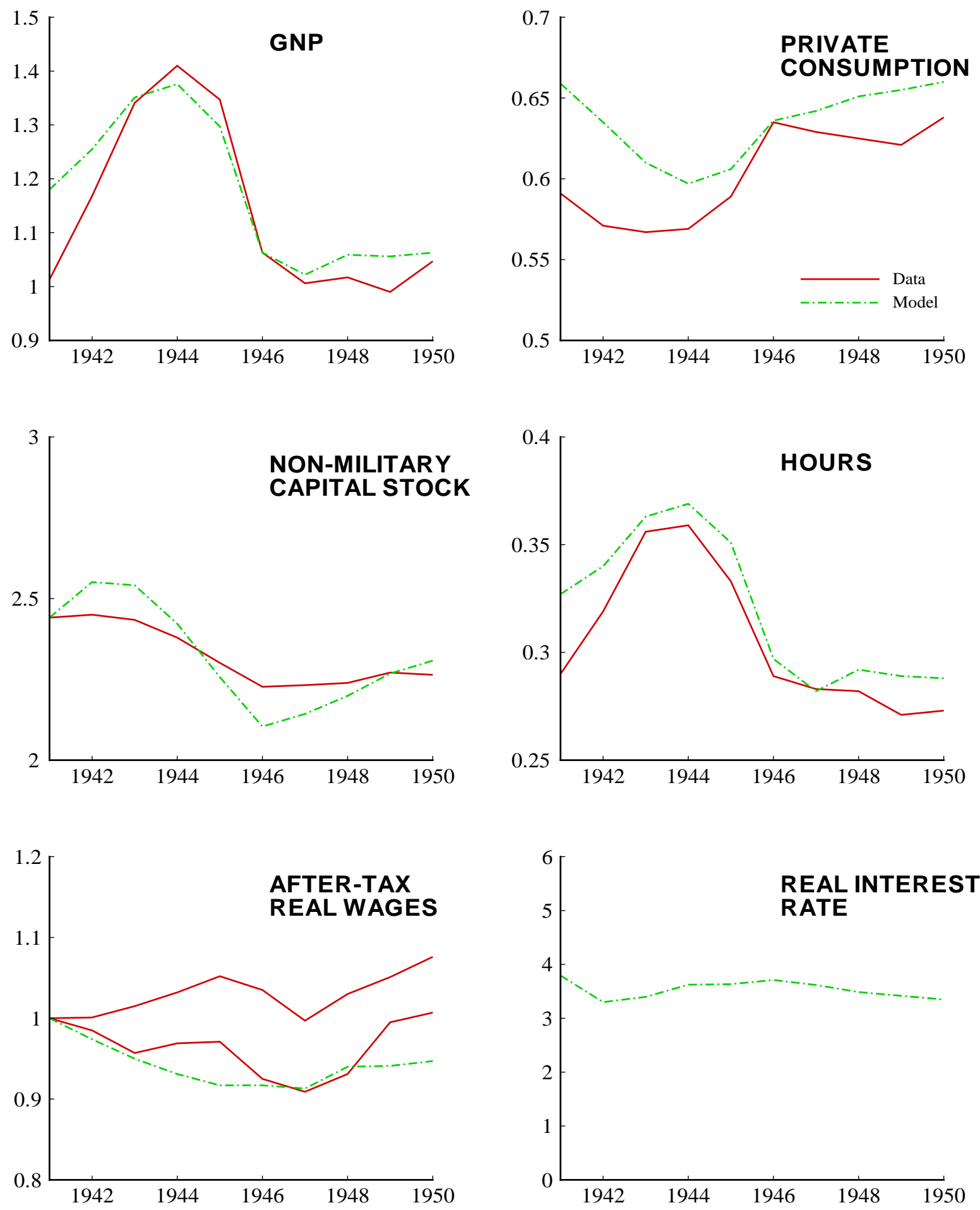

Figure 12. U.S. Time Series and Model Simulation with Greater Uncertainty about War's Duration (Experiment 5). 

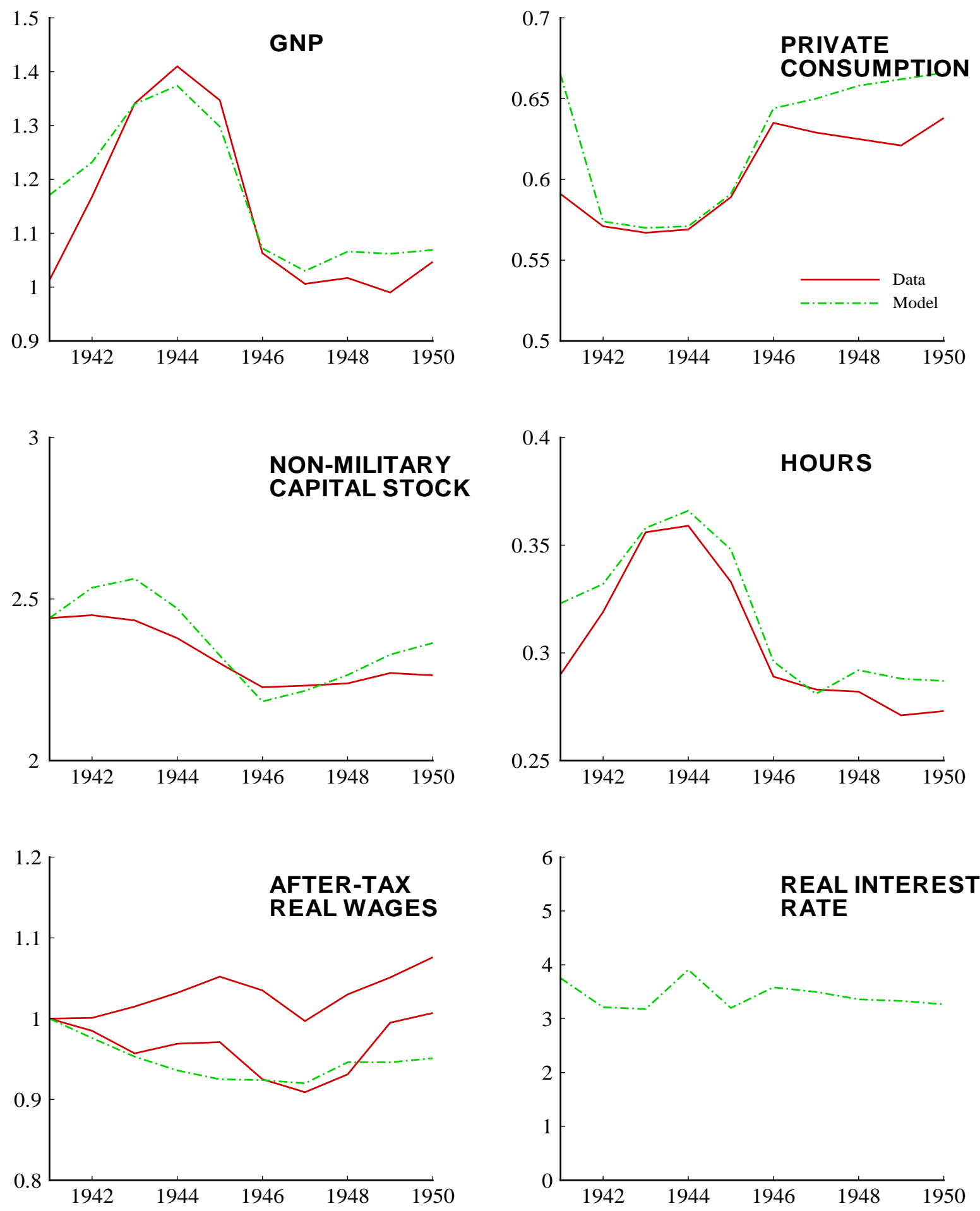

Figure 13. U.S. Time Series and Model Simulation with Greater Uncertainty about War's Duration and Rationing (Experiment 6). 

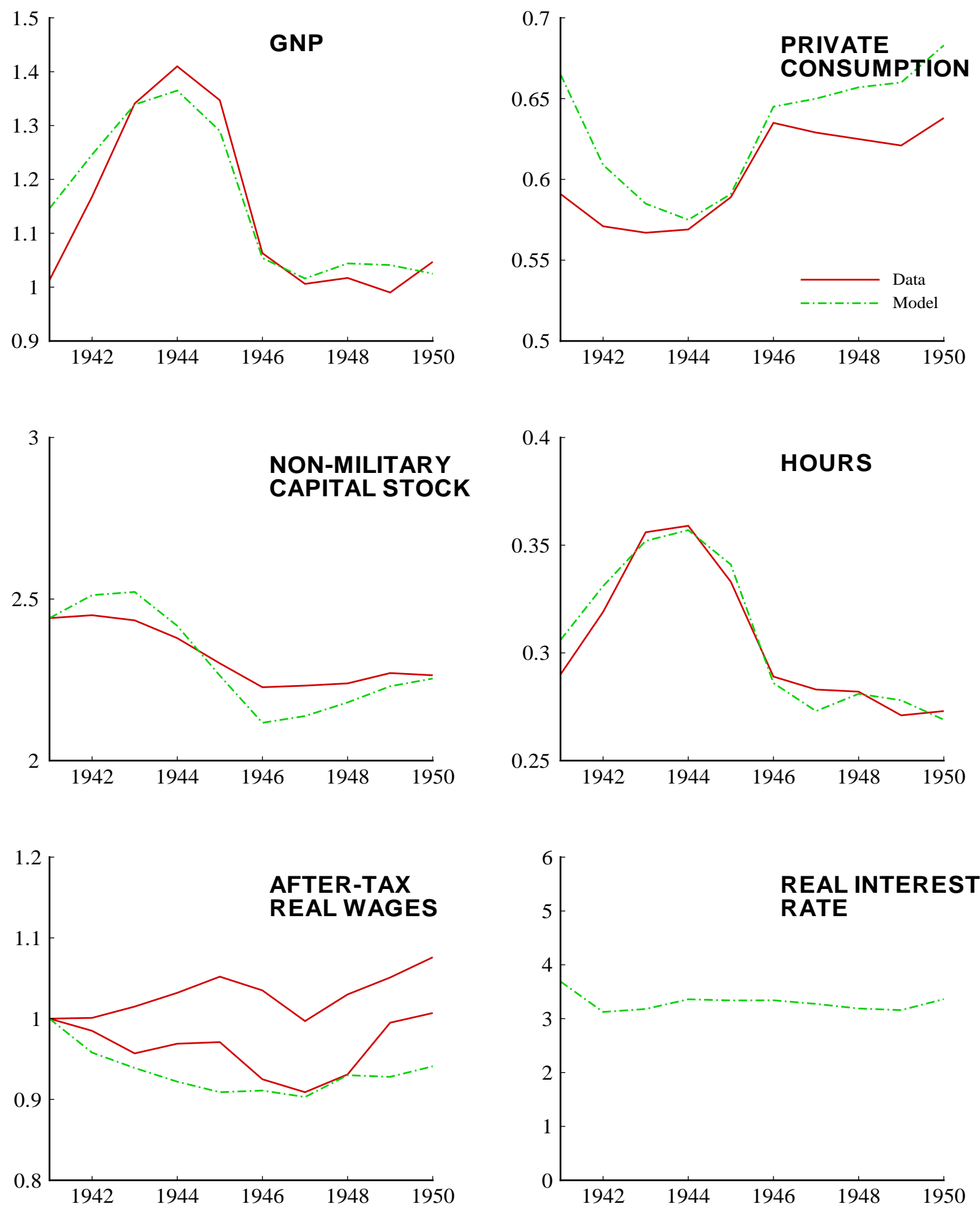

Figure 14. U.S. Time Series and Model Simulation with Fear of Depression (Experiment 7). 

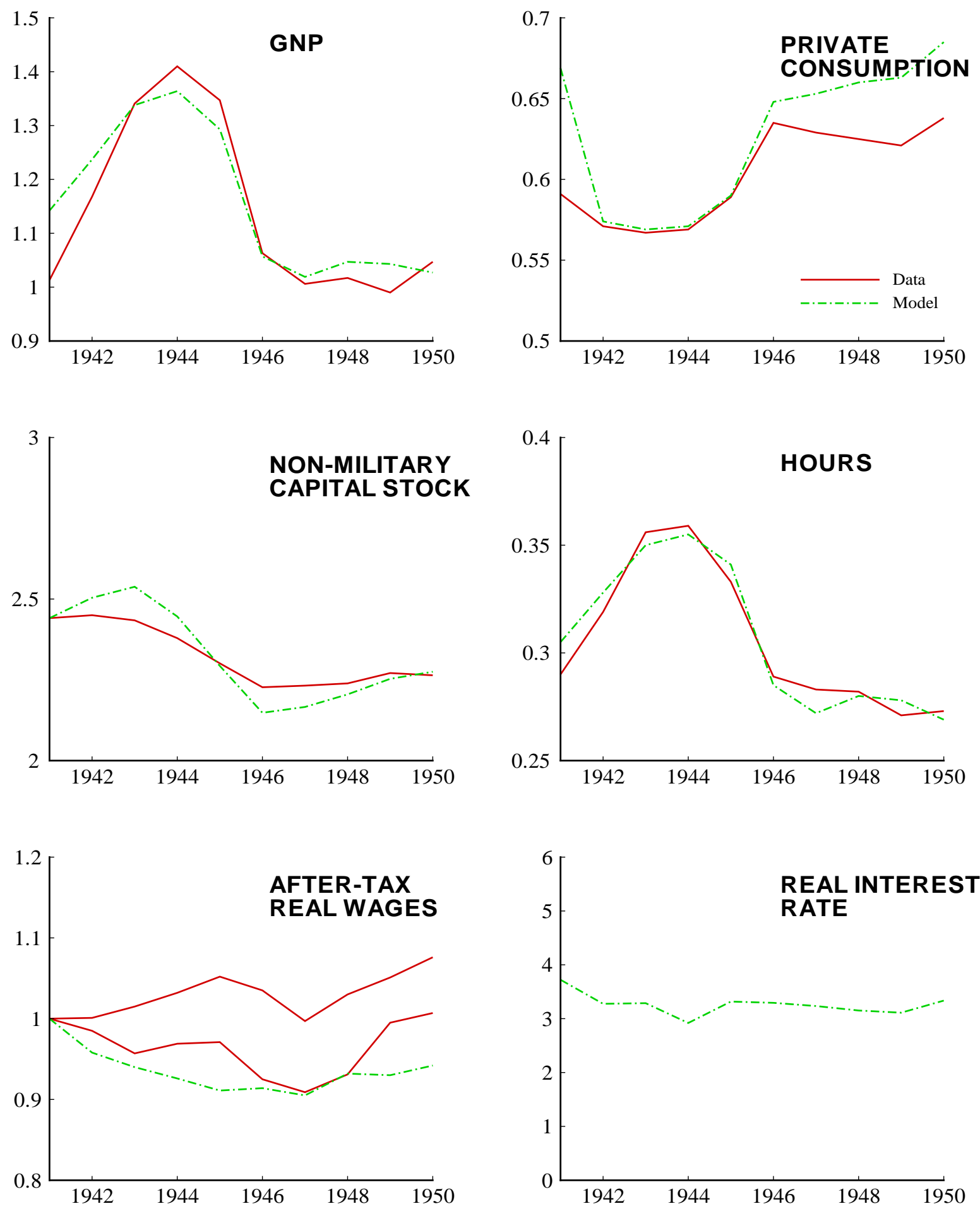

Figure 15. U.S. Time Series and Model Simulation with Fear of Depression and Rationing (Experiment 8). 